\title{
Management of pregnancy after augmentation cystoplasty
}

\author{
Catia Correia, Catarina Pardal, Joana Igreja
}

Gynecology and Obstetrics Department, Hospital de Braga, Braga, Portugal

Correspondence to Dr Catia Correia, catia_cor@hotmail.com

Accepted 1 May 2015
CrossMark

To cite: Correia $C$ Pardal C, Igreja J. BMJ Case Rep Published online: [please include Day Month Year] doi:10.1136/bcr-2015209304

\section{SUMMARY}

We report a case of successful pregnancy following augmentation ileocystoplasty in a patient with a neurogenic bladder dysfunction. A review of the literature reveals incidences of premature delivery and renal dysfunction. Careful urological monitoring of such patients should result in a successful pregnancy. Nevertheless, the unique clinical challenges and management options published to date are limited.

\section{BACKGROUND}

Augmentation cystoplasty is a surgical procedure that uses segments of bowel or stomach to provide increased bladder capacity in persons who lack adequate bladder function or detrusor compliance. This surgery is performed with increasing frequency; however, there are few reports of pregnancy after augmentation cystoplasty. ${ }^{1}$ Complications produced by pregnancy may endanger the patient (by disrupting reconstruction or impairing renal function) or her fetus (preterm delivery). The route of delivery should be determined by obstetrical indications. $^{2}$

\section{CASE PRESENTATION}

A 29-year-old patient G3P0A2 (1 miscarriage and 1 medical termination of pregnancy at 22 weeks due to spina bifida with Arnold Chiari Malformation Type II) underwent an augmentation ileocystoplasty 9 years prior due to a history of myelomeningocele and neurogenic bladder dysfunction. She performed intermittent self-catheterisation and had recurrent bacteriuria. Throughout the present pregnancy, urinalysis and serum creatinine levels were checked monthly. The urinalysis never showed proteinuria but revealed bacteriuria on three different occasions, and Escherichia coli was, on each occasion, isolated and treated with amoxicillin/clavulanate. The patient had two hospital stays for left renal colic with moderate hydronephrosis. However, her renal function remained stable.

Prenatal screening blood tests and ultrasound to neural tube defects were normal. Because of orthopaedic limitations to vaginal delivery (flaccid paraplegia, severe kyphoscoliosis and lack of movement abilities due to multiple surgical treatments of congenital hip dislocation), an elective caesarean section with tubal sterilisation was performed at the 38th week. Interdisciplinary urology and gynaecology cooperation was planned. The patient was given general anaesthesia due to anatomic inability to perform locoregional anaesthesia. A careful high (supraumbilical) midline laparotomy incision was performed, nevertheless, accidental injury to the bowel segment anastomosis occurred due to abdominal adhesion (figure 1). A lower segment caesarean section was performed after right lateral traction of the bowel segment anastomosis. A live male newborn was delivered, weighing $2985 \mathrm{~g}$, with 1 and 5 min Apgar scores of 7 and 9, respectively. Correction of the bowel anastomosis iatrogenic lesion was made using a double-layered 2-0 absorbable suture. We ruled out vascular lesion of the anastomosis pedicle (figure 2). Bladder integrity was assessed by vesical injection of saline solution (figure 3). A careful peritoneal lavage was carried out in order to prevent abdominal infection. The patient was placed on prophylactic antibiotics during the postpartum.

\section{OUTCOME AND FOLLOW-UP}

The patient was discharged home on the sixth postoperative day. Her urinary continence remained unchanged. No complications occurred in the early or late postpartum.

\section{DISCUSSION}

The first report on pregnancy in a patient with augmentation cystoplasty was published in $1955 .^{3}$ In order to provide better counselling to patients who have undergone urinary reconstruction and who desire to bear children, and to proper manage their pregnancies, more meaningful data about the incidence of complications are needed. However, a few case reports and series have been found in the literature providing some insight into this subject. ${ }^{4}$

Several reports describe uncomplicated pregnancies in these patients. However, urological

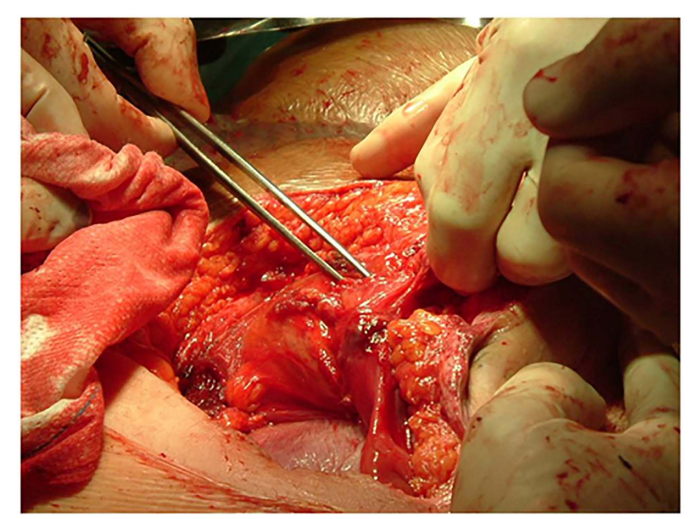

Figure 1 Injury to the bowel segment anastomosis occurred (a linear lesion about $1 \mathrm{~cm}$, as shown by dissection forceps). 


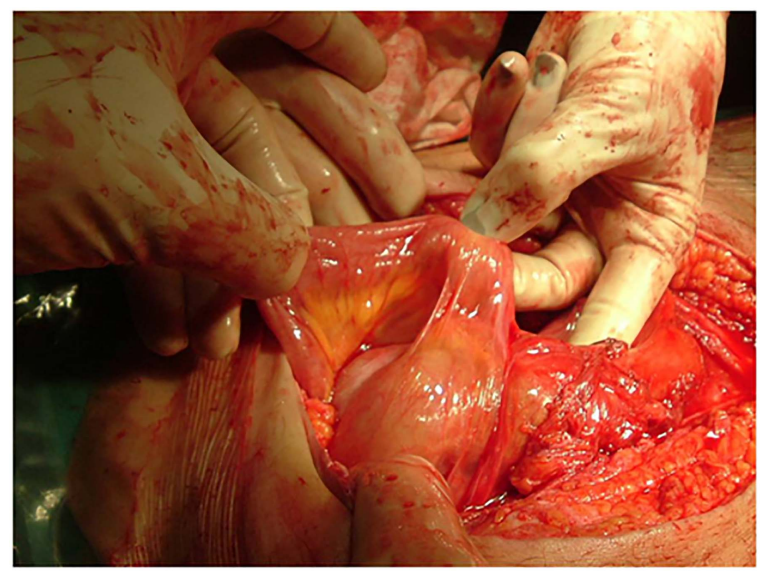

Figure 2 The vascular pedicle of the anastomosis was not injured.

complications such as urinary tract infections and hydronephrosis are the most common, and can lead to premature labour. Almost all the reports regarding pregnancy in patients with augmentation cystoplasty agree that urologists and obstetricians should be aware of and alert to urinary complications in order to ensure a good mother and fetus outcome. ${ }^{5}$

Regarding delivery, the major complications are lesions to the cystoplasty and its blood supply. There are some anatomical

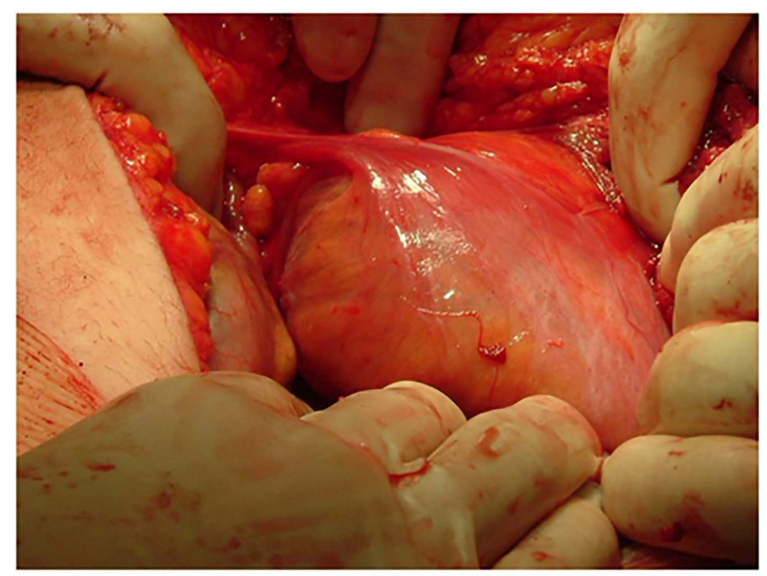

Figure 3 Bladder integrity was assessed by vesical injection of saline solution (no injury occurred). alterations, which occur after bladder augmentation, that need to be accounted for.

Some authors advocate an upper rather than lower segment caesarean section because of the risk of damage to the augmentation cystoplasty or its blood supply (it's fixed cranially by the mesentery, laterally by the ureter, and caudally by the trigone and urethra. When the uterus enlarges, it pushes the mesentery to one side and reaches up to the ventral abdominal wall). Previous pelvic surgery may also predispose to marked adhesions. $^{6}$

Other problems in patients with augmentation cystoplasty are metabolic complications such as hypokalaemic hyperchloraemic metabolic acidosis, hypocalcaemia, hypomagnesaemia and vitamin $\mathrm{B}_{12}$ deficiency.

\section{Learning points}

- Urinary tract infection in pregnant woman after augmentation cystoplasty should be carefully monitored and treated because of the known risk it poses to both mother and fetus.

- When a caesarean section is indicated, it must be very carefully performed by laparotomy to minimise the risk of bowel anastomosis injury.

- Interdisciplinary urology and gynaecology intervention is desirable for a successful outcome.

\section{Competing interests None declared.}

\section{Patient consent Obtained.}

Provenance and peer review Not commissioned; externally peer reviewed.

\section{REFERENCES}

1 Greenwell TJ, Venn SN, Creighton S, et al. Pregnancy after lower urinary tract reconstruction for congenital abnormalities. BJU Int 2003;92:773-7.

2 Shaikh A, Ahsan S, Zaidi Z. Pregnancy after augmentation cystoplasty. J Pak Med Assoc 2006;56:465-7.

3 Vordermark JS. Management of pregnancy after augmentation cystoplasty. Int Urogynecol J 1991;2:36-9.

4 Vordermark JS, Deshon GE, Agee RE. Management of pregnancy after major urinary reconstruction. Obstet Gynecol 1990;75:564-7.

5 Hensle TW, Bingham JB, Reiley EA, et al. The urological care and outcome of pregnancy after urinary tract reconstruction. BJU Int 2004;93:588-90.

6 Kapoor D, Chipde SS, Agrawal S, et al. Delivery after augmentation cystoplasty: implications and precautions. J Nat Sci Biol Med 2014;5:206-9.

\footnotetext{
Copyright 2015 BMJ Publishing Group. All rights reserved. For permission to reuse any of this content visit http://group.bmj.com/group/rights-licensing/permissions.

BMJ Case Report Fellows may re-use this article for personal use and teaching without any further permission.

Become a Fellow of BMJ Case Reports today and you can:

- Submit as many cases as you like

- Enjoy fast sympathetic peer review and rapid publication of accepted articles

- Access all the published articles

- Re-use any of the published material for personal use and teaching without further permission

For information on Institutional Fellowships contact consortiasales@bmjgroup.com

Visit casereports.bmj.com for more articles like this and to become a Fellow
} 